\title{
Testicular FSH receptor numbers and affinity in bulls of various ages*
}

\author{
J. A. Dias $†$ and J. J. Reeves \\ Department of Animal Science, Washington State University, Pullman, Washington 99164 , \\ U.S.A.
}

\begin{abstract}
Summary. Bulls $(N=42)$ ranging in age from 1 day to 5.5 years were used to determine whether a change in the concentration of FSH receptors in the bovine testis occurred as bulls matured. ${ }^{125}$ I-labelled human FSH was used as the ligand to evaluate binding to bovine testicular membranes. Membrane fractions were collected by centrifugation of testicular homogenates at $120 \mathrm{~g}$ and recentrifugation of the $120 \mathrm{~g}$ supernatant at $1250 \mathrm{~g}$. Relative binding activity of membrane sedimented at $1250 \mathrm{~g}$ was determined after incubation of membranes with ${ }^{125} \mathrm{I}$-labelled FSH for $16-18 \mathrm{~h}$ at $25^{\circ} \mathrm{C}$, followed by centrifugation $(1250 \mathrm{~g})$ to separate bound from free hormone. Specifically bound FSH when expressed as $\mathrm{fmol} / \mathrm{mg}$ protein was negatively correlated with age $(r=-0.73)$. The association constant $\left(K_{\mathrm{a}}\right)$ determined by Scatchard analysis was the same for bulls at all ages with a mean $(t$ s.e.m.) $K_{\mathrm{a}}=1.5 \pm 0.3 \times 10^{9} \mathrm{M}^{-1}$. Concentration of $\mathrm{FSH}$ receptors on a per $\mathrm{mg}$ protein basis declined rapidly from birth to 2.5 years of age and remained low up to 5.5 years of age. On a whole testis basis the total number of receptors increased as the bulls matured. After 2.5 years of age total testicular binding did not change.
\end{abstract}

\section{Introduction}

Gonadotrophic hormones have been proposed as the initiators of spermatogenesis in bulls (Hafs, Wettemann, Hackett \& Magee, 1968). In the male, studies of serum hormone changes together with target site responsiveness are crucial to understanding dynamic reproductive processes from birth to maturity. It has been demonstrated that stem cell numbers in the adult male testis depend on the increase in the Sertoli cell population during the prepubertal period (Hochereau-de Reviers \& Courot, 1978). Testicular FSH receptors are predominately located on Sertoli cells in the rat (Steinberger et al., 1975). Autoradiographic techniques have demonstrated binding of hCG and FSH to testicular tissue of immature bulls (Schanbacher, 1979), but neither serum LH nor FSH has been shown to be correlated with sperm production in bulls (Schanbacher, 1979; McCarthy, Convey \& Hafs, 1979). It therefore appears that changes in serum gonadotrophins alone do not account for the onset of spermatogenesis. Instead it has been suggested that a change in testicular sensitivity to gonadotrophins may be responsible for the onset of puberty (Odell \& Swerdloff, 1975; Schanbacher, 1979). Such a change may be mediated by changes in number or affinity of testicular FSH receptors. In the rat, a chronic proliferation of LH receptors occurs as the animal matures (Desjardins, Zeleznik, Midgley \& Reichert, 1975; Ketelslegers,

* Reprints requests to Dr J. J. Reeves.

† Present address: Department of Biochemistry, Albany Medical College of Union University, Albany, New York 12208 , U.S.A. 
Hetzel, Sherins \& Catt, 1978). Serum FSH in rats increases before spermatogenesis but is correlated with an increase in LH not FSH receptors (Ketelslegers et al., 1978). Binding capacity of ${ }^{125}$ I-labelled human FSH to bovine testis homogenates decreases with increasing testis weight (Abou-Issa \& Reichert, 1977), suggesting that there is a difference in the number of FSH receptors in bulls of different age. The objective of the present study was to evaluate the concentration and affinity of FSH receptors in testes of bulls from birth to maturity.

\section{Materials and Methods}

Hormone preparations. Highly purified human FSH (LER-1781-2, 4000 i.u./mg) was a gift from Dr L. E. Reichert, Jr of the Albany Medical College of Union University, Albany, New York. Ovine FSH (NIH-FSH-S12), ovine GH (NIH-GH-S10), ovine TSH (NIH-TSH-S6), ovine prolactin (NIH-PRL-S9) and ovine LH (NIH-LH-S17) were from the Pituitary Hormone Distribution Program, National Institute of Arthritis, Metabolic and Digestive Diseases, National Institutes of Health, Bethesda, Maryland.

Iodination of human FSH. FSH LER-1781-2 was iodinated with the precautions noted by Leidenberger \& Reichert (1972) and specific activity was determined by the method of Greenwood, Hunter \& Glover (1963). Then $10 \mu \mathrm{g}$ LER-1781-2 in $40 \mu \mathrm{l} \mathrm{H}_{2} \mathrm{O}, 20 \mu \mathrm{l} 0.05$ M-phosphate buffer, $\mathrm{pH} 7 \cdot 5$, and $1 \mathrm{mCi} \mathrm{Na}{ }^{125} \mathrm{I}$ were added to a reaction vial followed by addition of $5 \mu \mathrm{l}$ Chloramine $\mathrm{T}(6.0 \mathrm{mg} / \mathrm{ml})$ in $0.05 \mathrm{M}-\mathrm{NaHPO}_{4}, \mathrm{pH} 7.5$. The mixture was reacted for $90 \mathrm{sec}$ on ice. The reaction was stopped by addition of $10 \mu$ l sodium metabisulphite $(15.6 \mathrm{mg} / \mathrm{ml})$ in $0.05 \mathrm{M}-\mathrm{NaHPO}_{4}, \mathrm{pH} 7.5$. Transfer solution, $16 \%$ sucrose in $10 \% \mathrm{KI}$ with phenol red $(100 \mu \mathrm{l})$, was added to the vial and the entire mixture was purified on a Sephadex G-75 column $(0.8 \times 60 \mathrm{~cm})$. After chromatography, fractions were tested for receptor binding activity. Of the two elevated areas of radioactivity, only the first peak of radioactivity demonstrated binding to bovine testis homogenates or to antiserum to human FSH (NIAMDD Batch No. 4). The specific activity of the radioiodinated preparation ranged from 10 to 30 $\mu \mathrm{Ci} / \mu \mathrm{g}$.

Preparation of testicular homogenate. Holstein bulls ranging in age from 1 day to $5 \cdot 5$ years were used. Bulls were arranged in 11 age groups with 2-5 bulls in each group. Testes from bulls $<6$ months of age were collected immediately after castration while testes from bulls $>6$ months of age were acquired from the local slaughter house. All testes were collected over a period of $<1$ year, at random, so that freezing and storage effects on whole testes, if any, would be distributed throughout all age groups. Cheng (1975) did not find that freezing whole bovine testes had any effect on FSH receptors. Immediately after collection, testes were frozen and stored at $-20^{\circ} \mathrm{C}$ until assayed. After thawing, testes were cleaned of the epididymis and weighed with the tunica albuginea intact. An incision was made along the tunica albuginea and the parenchyma was everted, diced and weighed. The parenchyma was processed as described by Abou-Issa \& Reichert (1977) and Cheng (1975) with some modification. Tissue was diluted in buffer $(0 \cdot 3$ M-sucrose, $0.05 \mathrm{M}$-Tris- $\mathrm{HCl}, 25 \mathrm{mM}-\mathrm{MgCl}_{2}, \mathrm{pH} 7.5$ at $4{ }^{\circ} \mathrm{C}$ ) to $5 \mathrm{ml} / \mathrm{g}$ tissue and homogenized at maximum speed for $30 \mathrm{sec}$ with a Brinkman Polytron homogenizer. All tissue manipulations were done in a cold room $\left(4^{\circ} \mathrm{C}\right)$. The testicular homogenate was filtered through cheesecloth and the filtrate was centrifuged for $10 \mathrm{~min}$ at $120 \mathrm{~g}$. The pellet was discarded and the supernatant was centrifuged for $30 \mathrm{~min}$ at $1250 \mathrm{~g}$. The pellet was retained and resuspended as above to 1 $\mathrm{ml} / \mathrm{g}$ original testis weight. Aliquots of this preparation were retained for protein determinations (Lowry, Rosebrough, Farr \& Randall, 1953) using bovine serum albumin (BSA) as a reference. The remaining homogenate was frozen and stored in aliquots at $-20^{\circ} \mathrm{C}$ until all remaining tissues were processed for assay. The membrane preparations were assayed for FSH binding activity within 1 month after processing. The samples were thawed at $4^{\circ} \mathrm{C}$ and used only once for binding studies. Cheng (1975) did not find any loss in FSH binding activity of processed membranes of bovine testes stored frozen for up to 4 months. 
Binding of ${ }^{125}$ I-labelled human FSH to bovine testis homogenate. To determine the concentration of testicular FSH receptors in bulls of various ages, testis homogenates from each group were incubated with ${ }^{125} \mathrm{I}$-labelled FSH. The following reagents were added to $12 \times 75 \mathrm{~mm}$ glass tubes: $200 \mu \mathrm{l}$ Tris-BSA buffer $\left(10 \mathrm{~mm}\right.$-Tris- $\mathrm{HCl}, 0.1 \% \mathrm{BSA}, 25 \mathrm{mM}-\mathrm{MgCl}_{2}$, pH 7.5 at $\left.25^{\circ} \mathrm{C}\right), 100 \mu \mathrm{l}$ ovine FSH $(2 \mu \mathrm{g} / 100 \mu \mathrm{l})$ or $100 \mu \mathrm{l}$ Tris-BSA buffer without unlabelled hormone, $100 \mu \mathrm{l}{ }^{125}$ I-labelled FSH (100000 c.p.m.) and $150 \mu$ testis homogenate. Incubations were terminated at $20 \mathrm{~h}$ which was the time required to reach equilibrium at $25^{\circ} \mathrm{C}$ (Cheng, 1975). After incubation, $3 \mathrm{ml}$ of the Tris-BSA buffer $\left(4^{\circ} \mathrm{C}\right)$ were rapidly added to stop the reaction and the tubes were centrifuged at $1250 \mathrm{~g}$ for $30 \mathrm{~min}$. The supernatant was aspirated and radioactivity in the pellets was counted in a Nuclear Chicago gamma counter (efficiency $80 \%$ ). Non-specific binding determined by addition of a 100-fold excess of unlabelled ovine FSH was $20 \%$ of the total counts bound in the absence of unlabelled FSH. In the presence of 50-60 mg calf testis homogenate, $11-12 \%$ of the labelled hormone was bound. The sensitivity of the assay was 15 ng ovine FSH for a $20 \%$ displacement of labelled FSH. Numbers of receptors were assessed by comparing the amount of ligand bound to testis homogenates to a standard curve generated by incubating ${ }^{125} \mathrm{I}$-labelled FSH with increasing concentrations of homogenates from a standard homogenate pool. This method has been used to measure GnRH receptors in ovine pituitary tissue (Nett et al., 1981). The volumes of the pooled homogenate ranged from 25-500 $\mu$. The concentration of receptors in the testis homogenate standard pool was determined by Scatchard analysis (Scatchard, 1949). A saturation curve was generated by incubating a fixed amount of homogenate pool with increasing amounts of labelled hormone (3000-3000000 c.p.m., $0.09-40.0 \mathrm{ng}$ ). Non-specific binding was determined for each concentration of labelled hormone by addition of a 100 -fold excess of unlabelled ovine FSH with the homogenate and labelled hormone. The between-assay coefficient of variation was $10 \cdot 5 \%$.

To determine whether age affected the affinity constant $\left(K_{\mathrm{a}}\right)$ for the binding of FSH to testicular membrane receptors, 3 pools of homogenate were prepared from testes of 1-day-, 5-month- and 1-year-old bulls. A fourth pool consisting of testes from 1-day- to 6-month-old bulls was also prepared. The $K_{\mathrm{a}}$ of each pool was determined in duplicate analyses by displacement of labelled hormone with unlabelled hormone. The receptor concentrations of 3 of the testicular homogenate pools ( 1 day, 1 day -6 months, 1 year) were determined at several levels of each homogenate by comparison to the 5-month-testis homogenate pool used for the standard curve. The mean receptor content determined by this method agreed with the receptor concentration of each pool determined by Scatchard analysis.

The specificity of ${ }^{125}$ I-labelled human FSH binding to bovine testis homogenates was determined by incubating various concentrations of the ovine hormone preparations (NIHFSH-S12, NIH-GH-S10, NIH-TSH-S6, NIH-PRL-S9 and NIH-LH-S17) with a constant amount of ${ }^{125} \mathrm{I}$-labelled FSH and the receptor preparation. Assay conditions were the same as previously described.

\section{Affinity constants}

\section{Results}

The FSH binding data from a testis homogenate pool was best fitted by a linear regression analysis $\left(r^{2}=0.92, P<0.0001\right)$, indicating the presence of a single class of high affinity receptors with a mean ( \pm s.e.m.) equilibrium association constant of $3.12 \pm 1.9 \times 10^{9} \mathrm{M}^{-1}$ (Text-fig. 1). The number of FSH receptors in the pool averaged $102 \pm 16 \mathrm{fmol} / \mathrm{mg}$ protein. The $K_{\mathrm{a}}$ of the 4 homogenate pools from bulls of different ages were not affected by state of maturation and averaged $1.5 \pm 0.3 \times 10^{9} \mathrm{M}^{-1}$ (Table 1 ).

\section{Testicular weight}

The progressive change in testicular weight with increasing age is illustrated in Text-fig. 2(a). Testicular weight increased rapidly after Day 80 and growth appeared to plateau by 3 years of age. 

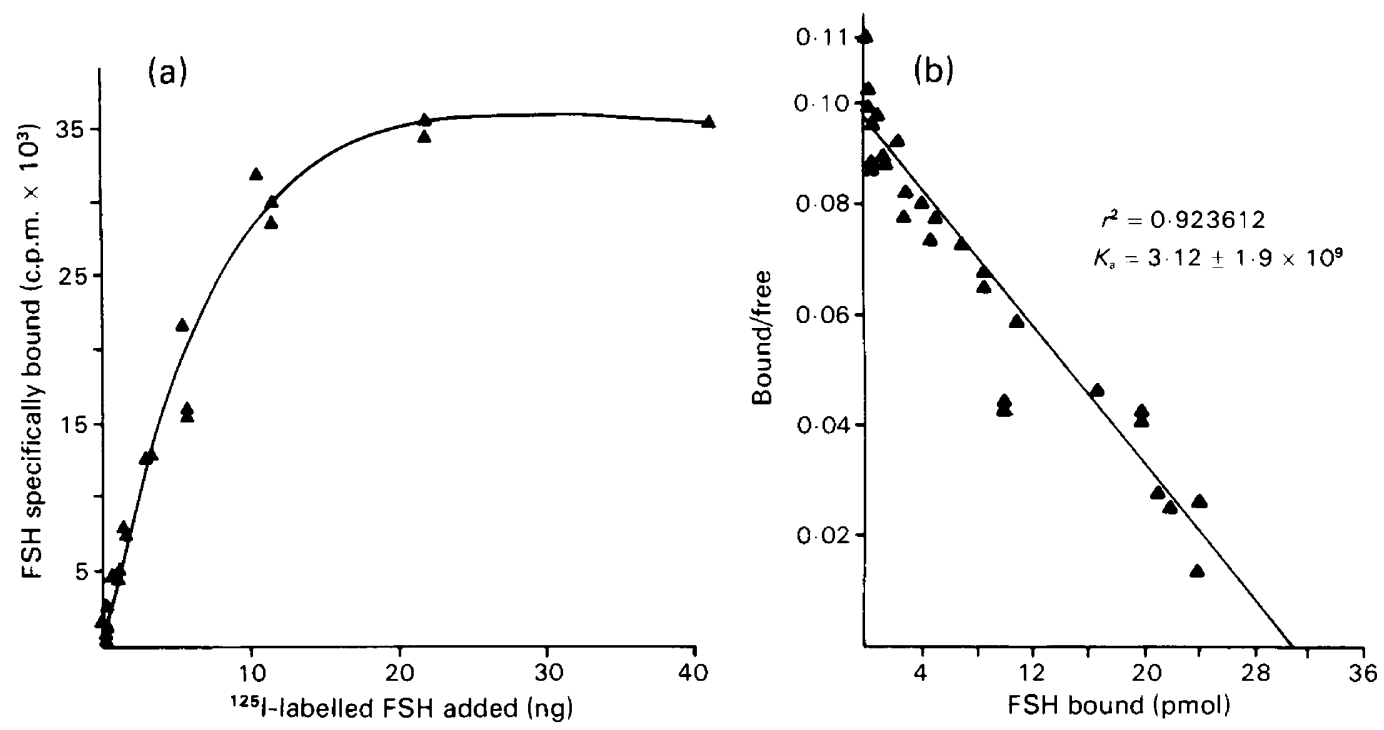

Text-fig. 1. (a) Saturation of bovine testicular homogenate with ${ }^{125}$ I-labelled human FSH (LER-1781-2) and (b) Scatchard analysis of the data. Each point is the mean of duplicate determinations in each of 3 assays on a pool of testicular homogenate. One class of high affinity sites is evident. The number of FSH receptors in the pool averaged $102 \pm 16 \mathrm{fmol} / \mathrm{mg}$ protein.

Table 1. Comparison of the measurement of FSH binding capacity of testicular homogenates by Scatchard analysis (A) or by comparison of unknown samples to a reference standard curve of increasing concentrations of homogenate containing a known quantity of receptor (B)

\begin{tabular}{lccccc}
\hline \multicolumn{1}{c}{ Age of bulls } & Exp. & $\begin{array}{c}\text { Affinity constant } \\
\left(\mathrm{M}^{-1}\right)\end{array}$ & $\begin{array}{c}\text { Scatchard Analysis* } \\
(\text { FSH bound mol/tube) }\end{array}$ & $\begin{array}{c}\text { Standard curve } \\
(\text { FSH bound mol/tube) }\end{array}$ & $\begin{array}{c}\text { Ratio } \\
\text { A/B }\end{array}$ \\
\hline \multirow{3}{*}{ I year } & & & A & B & \\
& 1 & $2.5 \pm 0.20 \times 10^{9}$ & $0.9 \pm 0.04 \times 10^{-13}$ & $1.4 \pm 0.6 \times 10^{-13}$ & 1.5 \\
I day-6 months & 2 & $1.9 \pm 0.24 \times 10^{9}$ & $0.8 \pm 0.07 \times 10^{-13}$ & $0.8 \pm 0.1 \times 10^{-13}$ & 1.0 \\
& 1 & $1.4 \pm 0.09 \times 10^{9}$ & $1.5 \pm 0.06 \times 10^{-13}$ & $1.5 \pm 0.4 \times 10^{-13}$ & 1.0 \\
1 day & 2 & $1.5 \pm 0.1 \times 10^{9}$ & $1.2 \pm 0.05 \times 10^{-13}$ & $1.5 \pm 0.3 \times 10^{-13}$ & 1.2 \\
& 1 & $0.7 \pm 0.12 \times 10^{9}$ & $2.5 \pm 0.30 \times 10^{-13}$ & $1.5 \pm 0.2 \times 10^{-13}$ & 0.63 \\
5 months (reference) & 2 & $0.9 \pm 0.10 \times 10^{9}$ & $1.9 \pm 0.15 \times 10^{-13}$ & $1.1 \pm 0.1 \times 10^{-13}$ & 0.59 \\
& 1 & $1.6 \pm 0.1 \times 10^{9}$ & $1.2 \pm 0.05 \times 10^{-13}$ & & $\overline{\mathbf{x}}=0.985$ \\
\hline
\end{tabular}

* Scatchard analysis was performed on each pool of homogenate representing different developmental stages (bull ages). The amounts of tissue per tube $(\mathrm{mg}$ wet $\mathrm{wt}$ ) for each group were 8.8, 24.9, 19.2 and 68.3 mg respectively. Affinity constants were calculated from the data of each analysis.

t The reference preparation ( 5 months) and the 1 day -6 months pool were diluted with assay buffer, $1 \mathrm{~g} / 10 \mathrm{ml}$. The membrane homogenate pool of 1-day-old calves was diluted $1: 20$ and that of the 1-year-old bulls was diluted $1: 5$. Increments of each dilution (range, 10-800 $\mu$ ) were incubated with $5 \mathrm{ng}{ }^{125}$ I-labelled hFSH in a final volume of $1 \mathrm{ml}$. Non-specific binding was determined by tubes which contained each amount of tissue and a 100 -fold molar excess of FSH. The relative potency estimate of each unknown preparation was determined by comparison to the reference curve. For the sake of comparison, the potency of each preparation is expressed as the moles of receptor per tube, estimated by comparison to the standard curve (see column B) and is compared to the mol receptor per tube which would be present as previously estimated by Scatchard analysis (see column A).

\section{Receptor concentrations}

Specific binding of ${ }^{125} \mathrm{I}$-labelled hFSH to bovine testicular membranes from bulls of various ages is illustrated in Text-figs 2(b) and 2(c). Binding decreased with age on a tissue protein basis, 


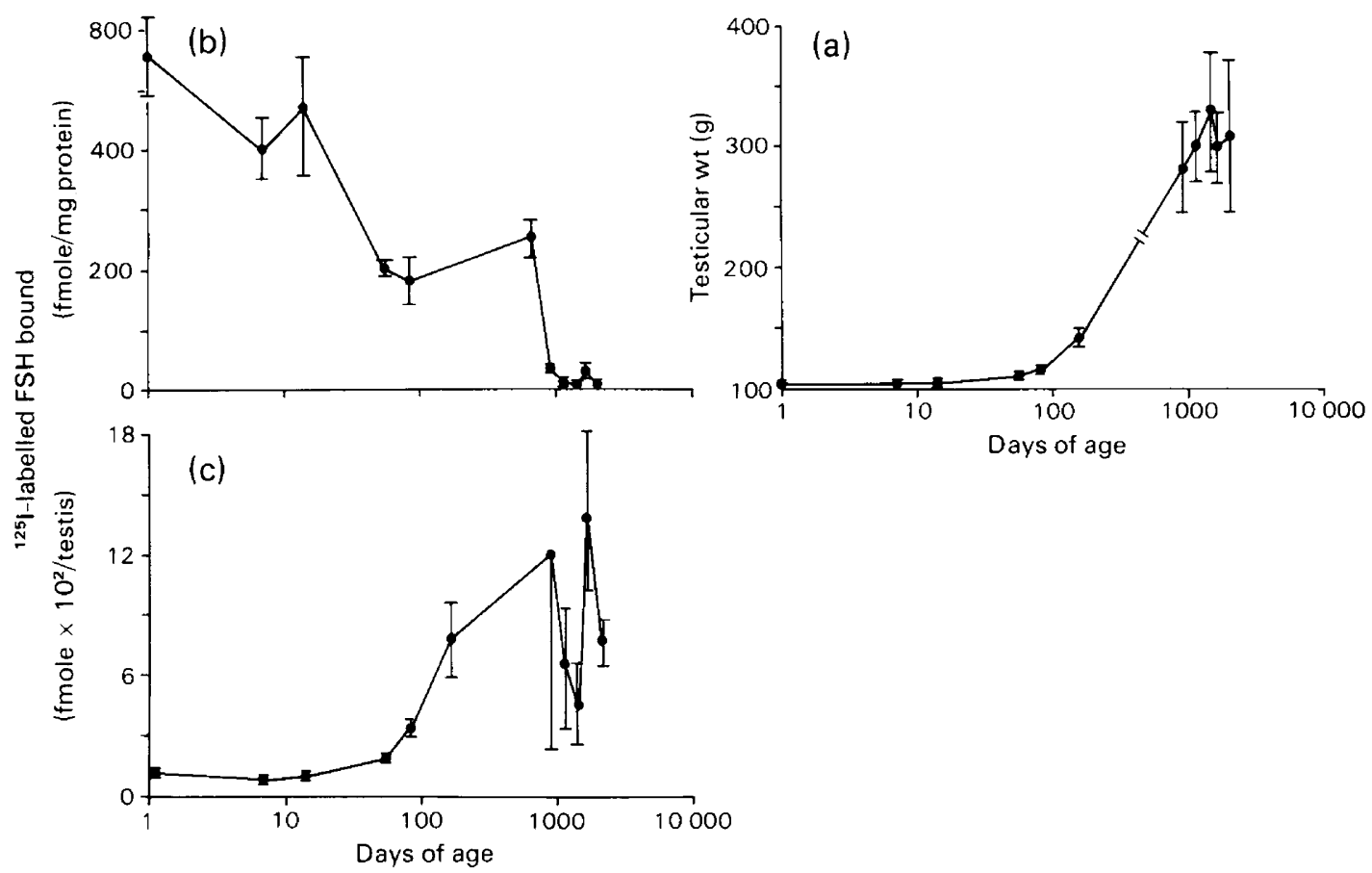

Text-fig. 2. Testicular weight and specific binding of ${ }^{125}$ I-labelled FSH by bovine testicular homogenates obtained from bulls at various ages. Data are represented as the mean \pm s.e.m. The numbers of animals within each of the 11 age groups were; 1 day, $5 ; 7$ days, $5 ; 14$ days $5 ; 56$ days, $5 ; 84$ days, $4 ; 168$ days, $3 ; 913$ days, $2 ; 1278$ days, $4 ; 1466$ days, $4 ; 1643$ days, $4 ; 2008$ days, 2 .

$r=-0.73, P<0.001$ (Text-fig. 2b). The decline in concentration of FSH receptors was pronounced before 2.5 years of age, but receptor concentration then remained low up to 5.5 years of age. However, on a whole testis basis the total testis receptor number increased as the bull matured (Text-fig. 2c). After 2.5 years of age, the total testis binding remained approximately the same, but not without great variation between bulls and within age groups. Thus, although receptor concentration declined during the first 2.5 years, the increase in testicular weight resulted in a net increase in total number of testicular receptors.

\section{Specificity of FSH receptors}

The binding of ${ }^{125} \mathrm{I}$-labelled FSH was specific and could be displaced by ovine preparations of NIH-FSH-S $12(80-20 \%$ inhibition $=110-14 \mathrm{ng})$ but not by NIH-PRL-S9 $(1000 \mathrm{ng})$ or NIH-GH-S10 (1000 ng). NIH-LH-S17 and NIH-TSH-S6 exhibited cross-reactions due to FSH contamination in those preparations at doses of $>1000 \mathrm{ng} /$ tube and $100 \mathrm{ng} /$ tube, respectively.

\section{Discussion}

This study demonstrated that the affinity constants of FSH receptors from bovine testes were similar at all the ages studied as reported by Abou-Issa \& Reichert (1977). Therefore, changes in the responsiveness of the testis to gonadotrophins during maturation could be due, in part, to changes in receptor content and not affinity. 
Receptor concentration estimates of testicular membranes determined by Scatchard analysis agreed with estimates obtained by comparing their binding activity to a reference homogenate with a known receptor concentration (Table 1). Receptor concentration estimates of bull testicular membranes of various ages were estimated by this method because of the limited quantity of membranes available from bulls at early ages. On a per $\mathrm{mg}$ protein basis FSH receptors decreased rapidly from birth to 2 months of age, then decreased more slowly from 2 months to 2.5 years of age. FSH receptor concentration in rat testis increases from birth until Day 10-15, then declines rapidly with age (Thanki \& Steinberger, 1978; Ketelslegers et al., 1978). Therefore, in the rat, FSH receptor concentration increases before puberty followed by a decrease during subsequent development. This study indicates that, in the bull, the highest concentrations of FSH receptors in testicular membrane homogenates were at birth. Although neonatal testes were not examined, it is possible that an increase in receptor concentration might occur in cattle in utero.

On a whole testis basis, the total receptor content increased up to 2.5 years in the bull and remained unchanged, although the between- and within-group variation was considerable after puberty. Similar variation in LH receptor concentration in adult pig testes has been reported (Peyrat, Meussy-Dessolle \& Garnier, 1981). Thus, although receptor concentration decreased, total testicular FSH binding capacity increased. Sperm production is dependent on the population of Sertoli cells in the prepubertal period (de Reviers et al., 1980). Since Sertoli cell mitosis is under FSH control (Griswold, Solari, Tung \& Fritz, 1977), some of the increase in total testicular FSH binding in bulls under 2.5 years of age may be due to post-natal proliferation of the Sertoli cell population. Changes in testicular weight due to spermatozoa, secreted fluid and connective tissue after puberty are known to occur (Courot, de Reviers \& Pelletier, 1975; Lunstra, Ford \& Echternkamp, 1979) and might constitute a source of error when estimating testicular receptor content on a whole testis basis. These changes might also account for the great variation in total testicular receptor numbers of mature bulls.

Studies of the dynamics of Sertoli cell proliferation and responsiveness relative to changes in FSH receptor concentration are essential to understanding the role of FSH in spermatogenesis. It is clear that the Sertoli cells of immature animals are more responsive to FSH than are those of mature animals (Means, Fakunding \& Tindall, 1975; Odell \& Swerdloff, 1975; Payne, Kelch, Murano \& Kerlan, 1977; Dorrington \& Armstrong, 1979). Whether the role of FSH in spermatogenesis is direct or indirect, the literature suggests that the decline in FSH receptor concentration in rats and mice is coincident with the decline in Sertoli cell responsiveness to FSH and an increase in Leydig cell responsiveness to LH (Ketelslegers et al., 1978). This study has demonstrated that in the bull testicular FSH receptor concentrations also decreased with age, although no increase in receptor concentration before the decline following birth was observed. It is possible that this change may occur in utero.

This is Scientific Paper No. 5430; College of Agriculture Research Center, Washington State University Project No. 0317.

\section{References}

Abou-Issa, H. \& Reichert, L.E., Jr (1977) Solubilization and some characteristics of the follitropin receptor from calf testis. J. biol. Chem. 252, 4166-4174.

Cheng, K.W. (1975) Properties of follicle-stimulatinghormone receptor in cell membranes of bovine testis. Biochem. J. 149, 123-132.

Courot, M., de Reviers, M.M. \& Pelletier, J. (1975) Variations in pituitary and blood LH during puberty in the male lamb. Relation to time of birth. Annls Biol. anim. Biochim. Biophys. 15, 509-516. de Reviers, M., Hochereau-de Reviers, M.T., Blanc, M.R., Brillard, J.P., Courot, M. \& Pelletier, J. (1980) Control of Sertoli cell and germ cell populations in the cock and sheep testes. Reprod. Nutr. Develop. 20 , 241-249.

Desjardins, C., Zeleznik, A.J., Midgley, A.R. Jr \& Reichert, L.E., Jr (1975) In vitro binding and autoradiographic localization of human chorionic and follicle stimulating hormone in rat testes during development. In Hormone Binding and Target Cell 
Activation in the Testes, pp. 221-236. Eds M. L. Dufau \& A. R. Means. Plenum Press, New York.

Dorrington, J.H. \& Armstrong, D.T. (1979) Effects of FSH on gonadal functions. Recent Prog. Horm. Res. 35, 301-342.

Greenwood, F.C., Hunter, W.M. \& Glover, J.S. (1963) The preparation of 131-I-labelled human growth hormone of high specific radioactivity. Biochem. $J$. 89, 114-123.

Griswold, M.D., Solari, A., Tung, P.S. \& Fritz, I.B. (1977) Stimulation by follicle stimulating hormone of DNA synthesis and of mitosis in cultured Sertoli cells prepared from the testes of immature rats. Molec. cell. Endocr. 7, 151-165.

Hafs, H.D., Wettemann, R.P., Hackett, A.J. \& Magee, W.T. (1968) Gonadotropins and sexual maturation of bulls. J. Anim. Sci. 27, 1191, Abstr.

Hochereau-de Reviers, M.T. \& Courot, M. (1978) Sertoli cells and development of seminiferous epithelium. Annls Biol. anim. Biochim. Biophys. 18, 573-583.

Ketelslegers, J.M., Hetzel, W.D., Sherins, R.J. \& Catt, K.J. (1978) Developmental changes in testicular gonadotropin receptors: plasma gonadotropins and plasma testosterone in the rat. Endocrinology 103 , 212-222.

Leidenberger, F. \& Reichert, L.E., Jr (1972) Evaluation of a rat testis homogenate radioligand receptor assay for human pituitary LH. Endocrinology 91, 901909.

Lowry, O.H., Rosebrough, N.J., Farr, A.L. \& Randall, R.J. (1953) Protein measurement with folin phenol reagent. J. biol. Chem. 193, 265-275.

Lunstra, D.D., Ford, J.J. \& Echternkamp, S.E. (1979) Serum hormonal changes and testicular response to LH during puberty in bulls. Biol. Reprod. 20, 1221-1227.

McCarthy, M.S., Convey, E.M. \& Hafs, H.D. (1979) Serum hormonal changes and testicular response to LH during puberty in bulls. Biol. Reprod. 20, $1221-1227$.
Means, A.R., Fakunding, J.L. \& Tindall, D.J. (1975) Follicle stimulating hormone regulation of protein kinase activity and protein synthesis in testis. Biol. Reprod. 14, 54-63.

Nett, T.M., Crowder, M.E., Moss, G.E. \& Duello, T.M. (1981) GnRH-receptor interaction. V. Down regulation of pituitary receptors for $\mathrm{GnRH}$ in ovariectomized ewes by infusion of homologous hormone. Biol. Reprod. 24, 1145-1155.

Odell, N.D. \& Swerdloff, R.S. (1975) The role of testicular sensitivity to gonadotropins in sexual maturation of the male rat. J. Steroid Biochem. 6 , $853-857$.

Payne, A.H., Kelch, R.P., Murano, E.P. \& Kerlan, J.T. (1977) Hypothalamic, pituitary and testicular function during sexual maturation of the male rat. $J$. Endocr. 72, 17-26.

Peyrat, J., Meussy-Dessolle, N. \& Garnier, J. (1981) Changes in Leydig cells and luteinizing hormone receptors in porcine testes during post-natal development. Endocrinology 108, 625-631.

Scatchard, G. (1949) The attractions of proteins for small molecules and ions. Ann. N.Y. Acad. Sci. 51, $660-672$.

Schanbacher, B.D. (1979) Relationship of in vitro gonadotropin binding to bovine testes and the onset of spermatogenesis. J. Anim. Sci. 48, 591-597.

Steinberger, A., Elkington, J.H.S., Sanborn, E.M., Steinberger E., Heindel, J.J. \& Lindsay, J.N. (1975) Culture and FSH responses of Sertoli cells isolated from sexually mature rat testis. In Hormonal Regulation of Spermatogenesis, pp. 399-410. Eds F. S. French, V. Hansson, E. M. Ritzen \& N. Nayfeh. Plenum Press, New York.

Thanki, K.H. \& Steinberger, A. (1978) Effect of age and hypophysectomy on FSH binding by rat testes. Andrologia 10, 195-202.

Received 3 September 1981 